\title{
EFEKTIFITAS PENGETAHUAN SAINS MELALUI PENDEKATAN EKSPLORASI LINGKUNGAN SEKITAR SEKOLAH DI TAMAN KANAK-KANAK NURUL JAMI'AH TALISE
}

\author{
Riza Indari ${ }^{1)}$ Fatimah Saguni ${ }^{2)}$ Marwany ${ }^{3)}$ \\ ${ }^{1}$ Mahasiswa Program Studi PIAUD FTIK Institut Agama Islam Negeri Palu \\ ${ }^{2}$ Dosen Fakultas Tarbiyah dan Ilmu Keguruan Institut Agama Islam Negeri Palu \\ ${ }^{3}$ Dosen Fakultas Tarbiyah dan Ilmu Keguruan Institut Agama Islam Negeri Palu
}

\begin{abstract}
ABSTRAK
Penelitian ini bertujuan untuk mengetahui Efektifitas pengetahuan sains melalui pendekatan eksplorasi lingkungan sekitar sekolah di Taman Kanak-kanak Nurul Jami'ah Talise. Penelitian ini menggunakan metode kualitatif. Teknik pengumpulan data melalui observasi wawancara dan dokumentasi. Tehnik analisis data yang digunakan adalah reduksi data, penyajian data dan penarikan kesimpulan. Hasil penelitian ini menunjukan bahwa dengan adanya pengetahuan sains anak dapat mengembangkan kognitifnya melalui kegiatan bermain sains di kelas maupun di luar kelas. Pengetahuan sains anak dapat diperoleh dengan bantuan guru yang melalukan pendekatan eksplorasi di lingkungan sekitar sekolah. Kegiatan mengeksplorasi mampu membuat anak merasa senang dan dapat lebih memahami tentang pengetahuan sains. Selain itu, dengan adanya pengetahuan sains melalui pendekatan eksplorasi, anak mendapat pengalaman baru dalam kegiatan belajar sambil bermain.
\end{abstract}

Kata Kunci : Sains, Pendekatan Eksplorasi

\section{PENDAHULUAN}

Pendidikan merupakan kebutuhan mutlak bagi kehidupan manusia yang harus dipenuhi. Pemenuhan kebutuhan pendidikan merupakan tanggung jawab bersama antara lingkungan keluarga (orang tua), lingkungan masyarakat dan lingkungan sekolah (lembaga pendidikan). Pendidikan adalah usaha sadar dan sistematis untuk mewujudkan suasana belajar dan proses pembelajaran sedemikian rupa agar peseta didik dapat mengembangkan potensi dirinya secara aktif agar memiliki pengendalian diri, kecerdasan, keterampilan dalam bermasyarakat, kekuatan spiritual keagamaan, kepribadian serta akhlak mulia yang dimulai sejak Pendidikan Anak Usia Dini (PAUD), Sekolah Dasar (SD), Sekolah Menengah Pertama (SMP), Sekolah Menengah Atas (SMA).

Pendidikan anak usia dini (PAUD) merupakan salah satu tahapan pendidikan yang dapat menentukan pertumbuhan dan perkembangan anak dimasa depannya. Karena pada Usia Dini perkembangan dan pertumbuhan anak berkembang sangat pesat jika selalu diisi dengan hal-hal yang positif dari kedua orangtua, guru dan lingkungan 
sekitarnya. Pendidikan Anak Usia Dini perlu mendapatkan perhatian yang sungguhsungguh dari pemerintah dan masyarakat karena merupakan langkah awal untuk menuju pendidikan yang lebih lanjut. Di samping itu, pendidikan anak usia dini merupakan investasi yang sangat besar bagi keluarga dan juga bangsa. Anak-anak adalah generasi penerus keluarga dan sekaligus penerus bangsa. Oleh karena itu sudah menjadi tanggung jawab para pendidik untuk dapat mendidik, membimbing dan mengarahkan anak-anak kearah yang lebih baik. Peran dari kedua orang tua yang sangat mempengaruh pertumbuhan dan perkembangan anak. Anak banyak menghabiskan waktu di rumah bersama orang tuanya. Serta meniru pola perilaku yang dilakukan oleh orang tua saat di rumah, baik yang terjadi didalam rumah ataupun di luar rumah.

Berikut adalah ayat tentang pentingnya sebuah pendidikan pada anak sejak usia dini yang terdapat pada Q.S Lukman (31:31).

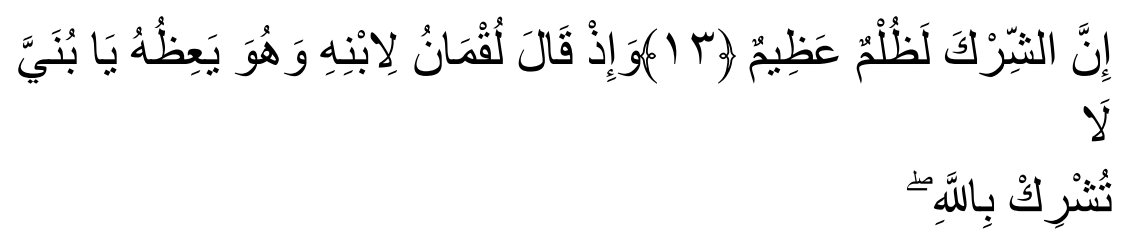

Terjemahannya:

"Dan (ingatlah) ketika Luqman berkata kepada anaknya, di waktu ia memberi pelajaran kepadanya: "Hai anakku, janganlah kamu mempersekutukan (Allah) sesungguhnya mempersekutukan (Allah) adalah benar-benar kezaliman yang besar"' .

Berbagai aspek perkembangan yang dapat dikembangkan dalam Pendidikan Anak Usia Dini yaitu fisik maupun psikis yang meliputi perkembangan intelektual atau kognitif, bahasa, motorik, dan sosio emosional. Dari seluruh aspek yang ada, aspek perkembangan kognitif adalah aspek utama yang dapat mempengaruhi perkembangan aspek yang lain. Pengenalan tentang sains hendaknya dilakukan sejak usia dini dengan kegiatan yang menyenangkan dan melalui pembiasaan agar anak mengalami proses sains secara langsung. Sains memungkinkan anak melakukan eksplorasi terhadap berbagai benda, baik benda hidup maupun mati. Selain itu juga dapat melatih anak menggunakan panca inderanya untuk mengenal berbagai gejala benda dan peristiwa. Eksplorasi dapat melatih anak melakukan proses percobaan terhadap berbagai benda disekitarnya untuk mengembangkan konsep sains anak usia dini.

Sains adalah bagian dari keseluruhan ilmu pengetahuan. Dalam sains setiap teori selalu didasarkan pada langkah eksperimen yang dapat dipertanggung

\footnotetext{
${ }^{1}$ Dep. Agama R.I, Alqur'an dan terjemahnya, (Mataram: Magfira Pustaka, 2006), 306.
} 
jawabkan secara akal sehat. Sains sendiri diambil dari bahasa latin scienta yang artinya pengetahuan. Pada dasarnya setiap anak dilahirkan dengan bakat untuk menjadi ilmuwan, ia dilahirkan dengan membawa sesuatu keajaiban yaitu dorongan rasa ingin tahu atau mencari tahu tentang apa yang ia lihat, dengar, dan rasakan di lingkungan sekitarnya.

Sujiono dkk menyatakan bahwa,

Hakikat pengembangan sains di Taman kanak-kanak adalah kegiatan belajar yang menyenangkan dan menarik dilaksanakan melalui bermain melalui pengamatan, penyelidikan dan pengetahuan sains untuk mencari tahu atau menemukan jawaban tentang kenyataan yang ada di dunia sekitar. ${ }^{2}$

Dalam kehidupannya sehari-hari anak-anak banyak melakukan eksplorasi terhadap lingkungannya baik dengan benda, binatang, tanaman, manusia, peristiwa atau kejadian. Biarkan anak memanfaatkan benda-benda yang ada disekitarnya dan biarkan anak melakukan trial dan error, karena memang anak adalah seorang penjelajah yang ulung. ${ }^{3}$ Dari Wikipedia Bahasa Inonesia, Ensiklopedia bebas mengartikan Eksplorasi adalah penjelajahan atau pencarian, mencari atau melakukan perjalanan dengan tujuan menemukan sesuatu. Misalnya daerah yang tidak dikenali yang berada di luar belahan bumi. ${ }^{4}$

Menurut Tylor (dalam buku Suyanto Slamet), Kegiatan eksplorasi memungkinkan anak untuk mengembangkan penyelidikan langsung melalui langkah-langkah spontan, belajar membuat keputusan tentang apa yang dilakukan, bagaimana cara melakukannya dan kapan melakukannya. ${ }^{5}$

Sedangkan menurut Koesoemadinata, Eksplorasi adalah kegiatan teknis ilmiah untuk mencari tahu suatu area, daerah, keadaaan, ruang yang sebelumnya tidak diketahui keberadaan akan isinya. Eksplorasi yang ilmiah akan memberikan sumbangan terhadap khazanah ilmu pengetahuan. Eksplorasi tidak hanya dilakukan disuatu daerah, dapat pula di kedalaman laut yang belum pernah dijelajah, ruang angkasa, bahkan wawasan alam pikiran eksloration of the mind. ${ }^{6}$

${ }^{2}$ Yuliani Nurani Sujiono dkk, Metode Pengembangan Kognitif, (Jakarta: Universitas Terbuka, 2006), 155

${ }^{3}$ Dwi Yulianti, Bermain Sambil Belajar Sains di Taman Kanak-Kanak, (Jakarta : PT. Indeks, 2010), 25

${ }^{4}$ (http://id.wikipedia.org/wiki/Eksplorasi), di akses pada hari Sabtu, 15 Desember 2018, pukul 08.52 Wita.

${ }^{5}$ Suyanto Slamet, Dasar dasar Pendidikan Anak Usia Dini, (Yogyakarta: Hikayat Publishing, 2005), 11.

${ }^{6}$ Masitoh, Strategi Pembelajaran TK, (Jakarta : Universitas Terbuka, 2007), 18. 
Dari hasil pengamatan yang dilakukan pada Kelompok B di Taman Kanakkanak Nurul Jami'ah Talise, kemampuan kognitif anak khususnya di bidang keterampilan proses sains masih rendah. Guru lebih sering menggunakan metode pemberian tugas menggunakan lembar kerja anak dan majalah bergambar sehingga kurang menarik minat anak terhadap sains. Kurang optimalnya dan efektifnya pembelajaran sains juga disebabkan pembelajaran yang masih terpusat pada guru, konsep sains yang diajarkan masih bersifat abstrak dan sulit dipahami karena anak tidak melakukannya secara langsung serta metode dan strategi pembelajaran yang diberikan kurang bervariatif.

Dalam sebuah pembelajaran dibutuhkan interaksi antara guru dan peserta didik, dalam pembelajaran juga dibutuhkan kerjasama yang baik antara guru dan peserta didik maupun antar sesama peserta didik. Peserta didik dijadikan sebagai subyek dalam pembelajaran, sedangkan guru bertindak sebagai fasilitator dalam proses pembelajaran. Keberhasilan dalam sebuah pembelajaran dapat dilihat dari peserta didik, apakah peserta didik aktif dalam pembelajaran dan mampu memahami serta menguasai materi yang diberikan oleh guru. Untuk itu seorang guru harus mampu mengolah dan mengelolah materi pembelajaran serta mampu mengaplikasikan model-model pembelajaran. Ada banyak cara yang dilakukan oleh guru dalam menyampaikan materi pelajaran agar peserta didik aktif dalam pembelajaran, yaitu dengan menggunakan model-model pembelajaran yang tepat. Ada beberapa model pembelajaran kooperatif yang dapat digunakan, salah satunya adalah model pembelajaran secara langsung terhadap anak yaitu dengan eksplorasi disekitar sekolah.

Berdasarkan berbagai alasan yang sudah diuraikan itulah mendorong peneliti untuk melakukan penelitian dengan judul "Efektifitas Pengetahuan Sains Melalui Pendekatan Eksplorasi Lingkungan Sekitar Sekolah Di Taman Kanak-kanak Nurul Jami'ah Talise".

\section{METODE PENELITIAN}

Metode penelitian yang digunakan adalah metode penelitian kualitatif deskriptif yaitu prosedur penelitian yang menghasilkan data deskriptif berupa katakata tertulis atau lisan dari orang-orang dan perilaku yang dapat diamati. Dengan demikian, penelitian ini mewujudkan dengan menafsirkan satu variabel, kemudian menghubungkannya dengan variabel data yang lain, dan disajikan dalam bentuk kata-kata atau kalimat naratif. Penelitian ini dilaksanakan di Taman Kanak-kanak Nurul Jami'ah Talise.

Pada penelitian ini peneliti mengumpulkan informasi dari orang-orang tertentu yang terlibat dalam pokok permasalahan yang diangkat. Pada penelitian ini yang menjadi objek untuk diwawancarai oleh peneliti adalah Kepala Sekolah 
Taman Kanak-kanak Nurul Jami'ah Talise, serta beberapa orang guru di Taman Kanak-kanak Nurul Jami'ah Talise.

Teknik pengumpulan data yang digunakan adalah teknik observasi, wawancara dan dokumentasi. Adapun teknik analisis data yang dilakukan meliputi reduksi data, penyajian data dan verifikasi data. Penelitian kualitatif memiliki derajat kepercayaan (credibility), keteralihan (transferability), ketergantungan (dependability), dan kepastian (confirmability). ${ }^{7}$ Penelitian kualitatif dilakukan dengan tujuan untuk memperoleh data yang akurat, pengecekan keabsahan data dilakukan dengan cara mengoreksi data satu persatu agar dapat diketahui kesalahan yang ada, kemudian akan disempurnakan lebih lanjut.

\section{HASIL DAN PEMBAHASAN}

\section{A. Efektivitas Pengetahuan Sains di Taman Kanak-kanak Nurul Jami'ah Talise}

Sains merupakan kebutuhan pokok bagi setiap individu untuk menghadapi zaman yang penuh dengan persaingan ini. Karena dengan sains, seseorang bisa dihormati dan diakui keberadaannya oleh masyarakat. Selain itu, sains juga menjadi salah satu indikator kemajuan suatu bangsa, karena pada dasarnya semua bidang kehidupan memerlukan sains. Pada anak usia dini sains mulai dikenalkan dengan cara yang sederhana dan mudah untuk anak pahami. Pengetahuan sains anak berbeda dengan orang dewasa pada umumnya. Anak akan menerima pengetahuan sains dengan cara melakukan praktek langsung bersama guru di sekolah.

Sujiono dkk menyatakan bahwa,

Hakikat pengembangan sains di Taman kanak-kanak adalah kegiatan belajar yang menyenangkan dan menarik dilaksanakan melalui bermain melalui pengamatan, penyelidikan dan pengetahuan sains untuk mencari tahu atau menemukan jawaban tentang kenyataan yang ada di dunia sekitar. ${ }^{8}$

Dari pendapat para ahli diatas dapat disimpulkan bahwa keterampilan proses sains untuk anak usia dini yang dimaksud dalam penulisan ini merupakan keterampilan anak dalam mengenal dan memahami ilmu dan konsep yang ada dalam sains. Dengan pengusaan sains diharapkan anak akan mengalami perubahan dan kemajuan dalam proses-proses sains seperti kemampuan klasifikasi, aktivitas eksploratif, inisiataif, dan pemecahan masalah. Dengan anak memahami proses

\footnotetext{
${ }^{7}$ Ibid, 164.

8 Yuliani Nurani Sujiono dkk, Metode Pengembangan Kognitif, (Jakarta: Universitas Terbuka,2006), 155
} 
pembelajaran sains akan memberi hasil belajar yang berkesan dan tidak mudah lupa.

Sains juga melatih anak menggunakan lima inderanya untuk mengenal berbagai gejala benda dan gejala peristiwa. Anak dilatih untuk melihat, meraba, membau, merasakan dan mendengar. Semakin banyak keterlibatan indera dalam belajar, anak semakin memahami apa yang dipelajari. Anak memperoleh pengetahuan baru hasil penginderaanya dengan berbagai benda yang ada disekitarnya. Pengetahuan yang diperolehnya akan berguna sebagai modal berpikir lanjut. Melalui proses sains, anak dapat melakukan percobaan sederhana. Percobaan tersebut melatih anak menghubungkan sebab dan akibat dari suatu perlakuan sehingga melatih anak berpikir logis.

Secara khusus sains di Taman Kanak-kanak menurut Yuliani Nurani Sujiono bertujuan agar anak memiliki kemampuan:

a) Dari mengamati perubahan-perubahan yang terjadi disekitanya, seperti perubahan antara pagi, siang dan malam ataupun perubahan dari benda padat menjadi cair.

b) Melakukan pengenalan pengetahuan sains sederhana, seperti biji buah yang ditanam akan tumbuh atau percobaan pada balon yang diisi gas akan terbang bila dilepaskan ke udara.

c) Melakukan kegiatan membandingkan, mengklasifikasikan serta mengkomunikasikan tentang sesuatu sebagai hasil sebuah pengamatan yang sudah dilakukannya. ${ }^{9}$

Dari pendapat para ahli tersebut, penulis mengambil sebuah kesimpulan dimana anak akan belajar menjadi pribadi yang mandiri dengan adanya pembelajaran sains yang diterapkan sejak usia dini. Dengan rasa keingintahuan anak dan memotivasi anak dalam memecahkan sebuah masalah yang ada di lingkungan sekitarnya khususnya pada bidang sains. Meningkatkan kreativitas dan keinovasian, khususnya dalam bidang ilmu pengetahuan alam, sehingga anak akan dapat memecahkan masalah yang dihadapinya. Seperti anak dapat menjangkau buah jambu diatas pohon dengan cara menyambung dua batang kayu yang pendek sehingga menjadi lebih panjang dan dapat dipergunakan sebagai alat bantu dalam bekerja. sains dengan metode bermain sambil belajar. Guru-guru diarahkan sehari sebelumnya menyiapkan alat peraga yang akan digunakan sehari sebelum proses pembelajaran.

Dalam mengenalkan sains guru biasanya memulai dari pengenalan macam-macam tanaman beserta warnanya. Guru membuat alat peraga berupa gambar tanaman yang sering anak-anak temui di sekelilingnya

\footnotetext{
${ }^{9}$ Yuliani Nurani Sujiono dkk. Metode Pengembangan Kognitif, (Jakarta: Universitas Terbuka, 2006), 12-13.
} 
untuk memudahkan anak dalam memahami seperti apa itu pengetahuan sains dalam kehidupan sehari-hari. Proses bermain sains dengan tanaman biasa dilakukan dengan cara anak memegang secara langsung jenis tanaman yang diperlihatkan oleh guru. Misalnya, pada saat guru membawa anak ke halaman sekolah yang terdapat tanaman putri malu yang jika disentuh akan menutup dirinya. Anak akan bertanya, mengapa daun pada putrid malu teetutup jika disentuh?. Guru harus memberikan jawaban yang konkrit dan dapat diterima oleh nalar anak. Penjelasan mengenai putri malu yang tertutup dapat dijelaskan bahwa tanaman putri malu merupakan tanaman yang peka terhadap sentuhan tangan manusia. Jadi, jika anak-anak menyentuhnya dia akan menutup seperti manusia yang sedang malu. Jawaban yang singkat dan mudah diterima oleh anak dapat membuatnya akan selalu ingat tentang sains yang dipelajari pada masa Taman Kanak-kanak. ${ }^{10}$

Dalam wawancara lain,

Pembelajaran sains yang biasa dilakukan khusus untuk anak usia dini yaitu dengan cara menyiapkan alat bermain sederhana setiap akan melakukan pembelajaran sains yang dapat menunjang perkembangan kognitif anak. Agar tercipta efektifnya pengetahuan sains bagi anak, guru biasanya menyiapkan alat dan bahan sehari sebelum pembelajaran dan mencari ide-ide yang kreatif untuk anak. Misalnya mengajarkan anak tentang pengenalan alam sekitar sekolah seperti, manfaat sinar matahari bagi kehidupan sehari-hari dengan mengajak anak langsung melihat matahari dan merasakan panasnya matahari serta dengan menggunakan alat peraga yang menarik agar anak lebih memahami tentang penjelasan guru.$^{11}$

Banyak hal yang dapat dilakukan oleh guru untuk mengefektifkan pengetahuan sains melalui eksplorasi di lingkungan sekitar sekolah khususnya dalam meningkatkan perkembangan kognitif pada anak usia dini, diantaranya dengan membuat ide kreatif agar saat mempelajari sains tercipta suasana yang menyenangkan dan mudah diingat anak hingga dewasa. Penulis melakukan wawancara dengan dua orang peserta didik untuk menanyakan pengalaman belajar mereka selama percobaan sains yang dilakukan oleh guru,

Belajar sains ternyata seru dan menyenangkan dibandingkan belajar hanya di dalam kelas sa ja dengan menggunakan gambar yang diwarnai. Mengenal secara langsung proses pembuatan kacang hijau yang

\footnotetext{
${ }^{10}$ Silih Hartati, S.Pd. Kepala Sekolah Taman Kanak-kanak Nurul Jami'ah Talise

"Wawancara" di ruang kelas, tanggal 23 April 2019

${ }^{11}$ Ardia, S.Pd. Guru Kelas Taman Kanak-kanak Nurul Jami'ah Talise "Wawancara” di ruang kelas, tanggal 23 April 2019
} 
berubag menjadi kecambah merupakan hal baru yang bagi anak yang hanya didapatkan saat di sekolah. ${ }^{12}$

Agar efektifnya pembelajaran sains dengan eksplorasi lingkungan sekitar sekolah guru membawa alat dan bahan dari rumah yang mudah di temukan. Proses pembelajaran tidak lepas dari kesesuaian antara RPPH dan kegiatan yang sedang berlangsung di sekolah. Guru menjadikan RPPH sebagai kiblat utama dalam melaksanakan pembelajaran di sekolah khususnya Taman Kanak-kanak sebagai alat pengukur perkembangan anak selama proses pembelajaran di sekolah. ${ }^{13}$

Guru sebagai pengelola proses pembelajaran harus mampu mengefektifkan suatu pembelajaran agar berjalan sesuai dengan kurikulum yang ada dan tingkat perkembangan anak usia dini. Banyak bukti yang membuktikan dengan kreatifitas yang dimiliki guru dalam mengenalkan pengetahuan sains pada anak dengan metode yang menarik bagi anak, mampu membuat anak merasa senang saat bermain sambil belajar dalam mengenal pengetahuan sains melalui eksplorasi lingkungan sekitar sekolah.

Mengajarkan tentang efektivitas pengetahuan sains pada anak usia dini dengan eksplorasi lingkungan sekitar sekolah merupakan tantangan tersendiri bagi seorang guru PAUD. Sebagai seorang guru PAUD dituntut harus memiliki kreatifitas yang tinggi serta mampu membuat suasana belajar lebih menyenangkan bagi anak selama di dalam kelas maupun saat belajar di luar kelas. Mengajarkan sains pada anak juga akan lebih efektif jika anak dilibatkan langsung dalam eksperimen. Pengetahuan yang mereka dapat dari aktivitas ini, umumnya akan jauh lebih melekat karena mereka akan cenderung mengingat apa yang pernah mereka lakukan. Jadi, sesekali guru harus mengajak anak untuk bermain sembari bereksperimen.

Salah satu eksperimen yang biasa dilakukan guru dan anak secara umum di Taman Kanak-kanak adalah melakukan percobaan menggunakan kacang hijau yang diubah menjadi kecambah dengan cara sederhana. Guru menyiapkan alat dan bahan dari rumah sehari sebelum melakukan proses pembelajaran. Sebelum melakukan eksperimen bersama anak, guru wajib mengenalkan alat dan bahan apa

\footnotetext{
${ }^{12}$ Raihan dan Salsabillah. Murid kelompok B Taman Kanak-kanak Nurul Jami'ah Talise "Wawancara” di halaman sekolah, 12 Agustus 2019

${ }^{13}$ Hermin, S.Pd. Guru Kelas Taman Kanak-kanak Nurul Jami'ah Talise "Wawancara" di ruang kelas, tanggal 24 April 2019
} 
saja yang akan digunakan, serta cara melakukan percobaan secara detail dengan penjelasan sederhana agar dapat dipahami oleh anak. ${ }^{14}$

Berdasarkan hasil wawancara di atas. Penulis dapat menyimpulkan bahwa efektivitas pengetahuan sains melalui eksplorasi lingkungan sekitar sekolah yang dilakukan harus secara kreatif dan dapat dilakukan langsung oleh anak. Agar proses pembelajaran sains dapat berlangsung dengan melakukan eksperimen langsung bersama anak. Dengan adanya pengetahuan sains yang di ajarkan oleh guru sejak usia Taman Kanak-kanak, anak dapat mengetahui tentang alam sekitarnya secara langsung dan belajar menjaga lingkungan sekitarnya yang ditanamkan sejak usia dini. Ketika anak dewasa nanti dapat menjadi generasi yang mencintai lingkungan sekitar sekolah dan rumahnya. Pada saat melakukan proses pembelajaran guru selalu menggunakan RPPH dan RPPM sebagai pedoman dalam melaksanakan proses pembelajaran di Taman Kanak-kanak. Tanpa komponen tersebut proses pembelajaran dikatakan tidak memenuhi syarat dalam sistem penilaian perkembangan anak dalam proses belajarnya. Sehingga pentingnya RPPH dan RPPM dalam mengajar untuk dimilki setiap guru yang akan mengajar.

\section{B. Pendekatan Eksplorasi di Lingkungan Sekitar Sekolah di Taman Kanak- kanak Nurul Jami'ah Talise}

Pendekatan eksplorasi adalah penjelajahan lapangan dengan tujuan memperoleh pengetahuan lebih banyak, terutama sumber alam terdapat ditempat itu. Eksplorasi merupakan jenis kegiatan permainan yang dilakukan dengan cara menjelajahi atau mengunjungi suatu tempat untuk mempelajari hal tertentu sambil mencari kesenangan atau sebagai hiburan dan permainan. Tujuan kegiatan eksplorasi dalam taman kanak-kanak adalah belajar mengelaborasi dan menggunakan kemampuan analisis sederhana dalam mengenal suatu objek. Proses stimulasi sangat dibutuhkan untuk perkembangan anak dan bisa diwujudkan dalam bentuk eksplorasi. Namun, bila eksplorasi atau aktivitas anak untuk memenuhi rasa ingin tahunya dilarang atau dihentikan, ini dapat membuat anak menjadi takut. Jika anak terus-menerus mengalami penolakan, dampaknya bisa berimbas pada kepribadiannya di masa mendatang. Saat bereksplorasi, anak akan mengalami proses belajar. Dari situlah akan terbentuk pribadi anak secara utuh.

Berdasarkan pengertian di atas, Penulis menemukan hasil wawancara dengan beberapa informan terkait pendekatan eksplorasi lingkungan sekitar sekolah, yaitu:

Pendekatan eksplorasi yang dilakukan dengan membawa anak dan mengenal secara langsung menuju alam sekitar yang ada di lingkungan sekitar sekolah, misalnya depan kelas yang terdapat banyak hal-hal

\footnotetext{
${ }^{14}$ Ardia, S.Pd. Guru Kelas Taman Kanak-kanak Nurul Jami’ah Talise "Wawancara” di ruang kelas, tanggal 24 April 2019
} 
yang bisa di lihat secara langsung oleh anak yang berhubungan dengan sains. Anak lebih menyukai belajar sambil melakukan eksperimen di luar kelas. Di halaman sekolah anak dapat melihat adanya pemandangan perbukitan dan lautan yang dapat secara langsung anakanak lihat dan ketahui seperti apa itu bukit dan lautan yang luas. Kebetulan jarak antara bukit dan laut tidak berada jauh dari lokasi sekolah. $^{15}$

Penulis juga melakukan wawancara dengan ibu Silih yang menyatakan:

Dalam proses pendekatan sains melalui eksplorasi lingkungan sekitar sekolah perlu adanya alat bermain yang mampu menunjang proses pembelajaran. Kepala sekolah harus mengambil peran sebagai fasilitator untuk menyediakan alat dan bahan atau wadah yang di butuhkan agar terciptanya pembelajaran yang lebih menyenangkan bagi anak. Serta mengusahakan ketersediaan sarana dan prasarana di sekolah. Kepala sekolah bekerja sama dengan guru serta ketua yayasan dalam merencanakan terciptanya proses pembelajaran sains yang bernilai edukatif bagi anak usia dini. Alat permainan edukatif merupakan penunjang utama anak dalam proses belajar sambil bermain di sekolah. Permainan harus mampu mengikuti perkembangan zaman, terutama dalam melakukan eksplorasi guru harus menggunakan alat permainan yang kreatif dan inovatif serta mudah untuk dijumpai. Salah satu alat permainan edukatif yang mengikuti dalam melakukan eksplorasi lingkungan sekitar sekolah adalah pembuatan hewan dan tanaman dari sebuah kardus yang bernilai edukatif dalam mengenalkan anak mengenai makhluk hidup di sekitarnya. ${ }^{16}$

Pendekatan eksploratif di Taman Kanak-kanak Nurul Jami'ah Talise berkembang sebagai pendekatan pembelajaran dalam bidang lingkungan atau sains. Dengan adanya pendekatan eksplorasi merupakan proses kerja dalam memfasilitasi proses belajar anak dari tidak tahu menjadi tahu. Anak memperoleh pengalaman belajarnya dengan cara melihat, menyentuh, dan merasakan secara langsung. Mereka akan menggambarkan pemahaman yang mendalam untuk memberikan respon yang mendalam juga setelah mengalami secara langsung dalam mengenal sains.

Berdasarkan penjelasan di atas, Penulis menemukan hasil wawancara dengan beberapa informan tentang kendala yang dihadapi oleh guru ketika melakukan pendekatan sains dengan eksplorasi lingkungan sekitar sekolah bersama anak, yaitu:

\footnotetext{
${ }^{15}$ Noviani, S.Pd. Guru Kelas Taman Kanak-kanak Nurul Jami’ah Talise "Wawancara” di ruang kelas, tanggal 26 April 2019.

${ }^{16}$ Silih Hartati, S.Pd. Kepala Sekolah Taman Kanak-kanak Nurul Jami'ah Talise

"Wawancara" di ruang kelas, tanggal 26 April 2019.
} 
Kendala yang paling umum pada pendekatan eksplorasi lingkungan sekitar sekolah adalah saat guru menjelaskan anak biasanya banyak yang tidak fokus atau hanya bermain bersama temannya saat guru menjelaskan mengenai sains. Hal tersebut biasanya terjadi jika cara guru yang menjelaskan kurang menarik perhatian anak. Sehingga saat melakukan proses pembelajaran anak menyelesaikan tugasnya tidak sesuai yang di jelaskan guru dan hanya asalasalan saja. Kadang anak sama sekali tidak ingin mengerjakan tugasnya dan tidak ingin melakukan proses bermain bersama guru sehingga menjadi kendala bagi guru untuk menilai perkembangan anak dalam pembelajaran sains saat melakukan eksplorasi lingkungan sekitar sekolah. Banyaknya kendala merupakan tantang bagi seorang guru PAUD untuk menciptakan suasana belajar yang tidak membosankan bagi anak. Dalam mengatasi kendala anak dalam memahami sains, guru biasanya membuat lagu yang berhhubungan dengan sains yang membuat suasana jadi menyenangkan dan membuat anak ceria untuk belajar. ${ }^{17}$

\section{Dalam wawancara lain,}

Jika pembelajaran tidak tuntas pada hari itu, guru biasanya mengulang kembali kegiatan ekperimen sains di esok harinya hingga anak mulai bisa memahami apa yang diajarkan pada hari itu. Guru tidak boleh membiarkan anak hanya mengenal sekali saja kemudian membiarkan anak tidak paham dengan apa yang sudah di ajarkan pada hari itu. Di sisi lain anak tidak boleh dipaksakan untuk memahami suatu pembelajaran, dikarenakan setiap anak memiliki cara penangkapan yang yang berbeda, ada yang cepat dalam memahami sesuatu dan ada yang lambat dalam memahami. Perlu adanya evaluasi pembelajaran yang sudah dilakukan pada disetiap akhir pertemuan, agar guru mengetahui sejauh mana perkembangan anak dalam pembelajaran sains. Dalam mempelajari sains butuu tingkat kesabaran yang tingi bagi seorang guru dalam mengajarkannya. Anak perlu dikenalkan secara perlahan-lahan dan secara detail. Jika penjelasan seorang guru tidak jelas, anak akan sering bertanya secara terus-menerus hingga anak merasa paham dengan jawaban yang guru berikan. ${ }^{18}$

Berdasarkan hasil wawancara di atas, Penulis dapat menyimpulkan bahwa pendekatan sains melalui eksplorasi lingkungan sekitar sekolah merupakan hal yang penting bagi anak. Anak dapat mengenal sains melalui lingkungan sekitarnya dengan bantuan guru di sekolah maupun dengan orang tua di rumah. Dengan adanya kegiatan eksplorasi secara langsung dan tidak melakukan proses bermain hanya di dalam kelas saja anak dapat dengan aktif bergerak untuk perkembangan motoriknya. Anak juga dapat mengembangkan pengetahuannya melalui kegiatan ekplorasi. Banyak hal yang

\footnotetext{
${ }^{17}$ Ardia, S.Pd. Guru Kelas Taman Kanak-kanak Nurul Jami'ah Talise "Wawancara” di ruang kelas, tanggal 26 April 2019.

${ }^{18}$ Hermin, S.Pd. Guru Kelas Taman Kanak-kanak Nurul Jami'ah Talise "Wawancara" di ruang kelas, tanggal 26 April 2019
} 
dapat anak peroleh dengan melakukan eksplorasi langsung. Ketika anak mengenal sains dengan eksplorasi, anak akan menjadi termotivasi dalam mencapai cita-citanya kelak untuk menjadi seorang ilmuwan. Pengenalan sains untuk anak pra sekolah lebih ditekankan pada proses daripada produk. Untuk anak prasekolah keterampilan proses sains hendaknya dilakukan secara sederhana sambil bermain. Kegiatan sains memungkinkan anak melakukan eksplorasi terhadap berbagai benda, baik benda hidup maupun benda tak hidup yang ada disekitarnya. Anak belajar menemukan gejala benda dan gejala peristiwa dari benda-benda tersebut.

Menurut Tylor (dalam buku Suyanto Slamet),
Kegiatan eksplorasi memungkinkan anak untuk
mengembangkan penyelidikan langsung melalui langkah-
langkah spontan, belajar membuat keputusan tentang apa yang
dilakukan, bagaimana cara melakukannya dan kapan
melakukannya. ${ }^{19}$

Sedangkan menurut Koesoemadinata, Eksplorasi adalah kegiatan teknis ilmiah untuk mencari tahu suatu area, daerah, keadaaan, ruang yang sebelumnya tidak diketahui keberadaan akan isinya. Eksplorasi yang ilmiah akan memberikan sumbangan terhadap khazanah ilmu pengetahuan. Eksplorasi tidak hanya dilakukan disuatu daerah, dapat pula di kedalaman laut yang belum pernah dijelajah, ruang angkasa, bahkan wawasan alam pikiran eksloration of the mind. ${ }^{20}$

Dari pendapat para ahli tersebut, penulis mengambil kesimpulan bahwa ekplorasi adalah sebuah kegiatan yang dapat menyenangkan bagi anak usia dini. Dimana anak dapat melihat, merasakan dan mengalami secara langsung kegiatan pembelajaran dengan ekplorasi lingkungan sekitarnya. Pendekatan belajar yang eksploratif tidak hanya berfokus pada bagaimana mentransfer ilmu pengetahuan, pemahaman, dan interpretasi, namun harus diimbangi dengan peningkatan mutu materi ajar. Informasi tidak hanya disusun oleh guru. Perlu ada keterlibatan siswa untuk memperluas, memperdalam, atau menyusun informasi atas inisiatifnya.

Dari konsep di atas penulis mengambil kesimpulan bahwa kegiatan eksplorasi harus dilakukan secara aktif agar mendapatkan hasil yang maksimal dan dapat menjadi pengetahuan bagi yang lainnya. Pendekatan pembelajaran yang berkembangan saat ini secara empirik telah melahirkan disiplin baru pada proses belajar sains anak. Tidak hanya berfokus pada apa yang anak temukan, namun bagiamana cara mengeksplorasi ilmu pengetahuan. Dalam mengeksplorasi anak akan menemukan pengalaman belajar yang baru dan jauh lebih menyenangkan dibandingkan saat belajar di dalam kelas

${ }^{19}$ Suyanto Slamet, Dasar dasar Pendidikan Anak Usia Dini, (Yogyakarta: Hikayat Publishing, 2005), 11.

${ }^{20}$ Masitoh, Strategi Pembelajaran TK, (Jakarta : Universitas Terbuka, 2007), 18. 


\section{KESIMPULAN}

Berdasarkan hasil pembahasan dalam penelitian ini, maka penulis dapat mengemukakan beberapa kesimpulan yakni sebagai berikut:

1. Efektivitas pengetahuan sains di Taman Kanak-kanak Nurul Jami'ah Talise telah dibuktikan dengan hasil pengamatan pada proses pembelajaran saat anak didik terlihat aktif dan antusias saat guru mengajarkan tentang pembelajaran sains dengan beberapa alat peraga yang sederhana. Anak sangat aktif berbicara untuk mengemukakan tentang pengalamannya yang berhubungan dengan pengetahuan sains dalam kehidupan sehari-hari saat melakukan praktek langsung. Pada saat melakukan kegiatan langsung bersama guru dalam pembelajaran sains mampu merangsang perkembangan kognitif pada anak dimana usia Taman Kanak-kanak perkembangan kognitif anak berkembang dengan sangat baik jika diberi stimulus yang baik oleh guru maupun orang tua di rumah.

2. Metode pendekatan eksplorasi lingkungan sekitar di Taman Kanak-kanak Nurul Jami'ah Talise dapat dikatakan sebagai metode yang sangat baik karena potensi alam sekitar sekolah sangat membantu guru dalam mengenalkan tentang sains kepada anak dengan melakukan kegiatan eksplorasi. Anak dapat melihat dan bersentuhan dengan alam yang ada di sekitar sekolah. Anak juga dapat mengetahui manfaatnya bagi makhluk hidup yang ada di bumi. Seperti manfaat dari sinar matahari sebagai penerang bagi bumi, untuk manusia dalam kehidupan sehari-hari dan bagi tumbuh-tumbuhan

\section{SARAN}

Sebagai tindak lanjut penelitian yang Penulis lakukan maka ada beberapa saran sebagai berikut:

1. Efektivitas pengetahuan sains yang di lakukan dengan ekplorasi lingkungan sekitar sekolah merupakan sesuatu yang sangat penting di ajarkan pada anak usia dini. Agar membantu proses perkembangan kognitif pada anak dan dapat melatih psikomotoriknya. Oleh karena itu, setiap Taman Kanak-kanak wajib menghidupkan proses pembelajaran sains dengan membawa anak langsung melihat dan mengenal objek yang di ajarkan oleh guru dengan pendekatan sains yang mudah dan sederhana. Serta mampu menarik minat anak terhadap pembelajaran sains sebagai bekal pengetahuannya di masa depan yang merupakan generasi penerus bangsa.

2. Untuk sekolah agar selalu memberikan hal-hal kreatif dalam mengenalkan sains kepada anak. Selain itu, menambahkan buku-buku dongeng mengenai sains dan alat peraga yang menunjang hasil belajar anak untuk suksesnya pembelajaran sains di Taman Kanak-kanak.

3. Untuk guru kelas maupun guru pendamping agar mempertahankan apa yang sudah dilakukan dan berusaha mengurangi kekurangan yang terjadi saat proses 
pembelajaran. Selain itu, dengan memperluas wawasan dalam hal pembuatan alat permainan edukatif sesuai dengan perkembangan zaman sekarang, agar dalam proses pembelajaran anak tidak merasa jenuh dan dapat sesuai dengan kebutuhan aspek perkembangan anak.

4. Bagi peneliti lanjutan, penelitian ini terbatas pada pengetahuan sains melalui eksplorasi, maka perlu adanya penelitian lebih lanjut dalam bidang kemampuan anak yang lainnya yang belum pernah dilakukan

\section{DAFTAR PUSTAKA}

Dep. Agama R.I, Alqur'an dan terjemahnya, (Mataram : Magfira Pustaka, 2006).

Dwi Yulianti, Bermain Sambil Belajar Sains di Taman Kanak-Kanak, (Jakarta : PT. Indeks, 2010).

Masitoh, Strategi Pembelajaran TK, (Jakarta : Universitas Terbuka, 2007), 18.

Suyanto Slamet, Dasar dasar Pendidikan Anak Usia Dini, (Yogyakarta : Hikayat Publishing, 2005).

Yuliani Nurani Sujiono dkk, Metode Pengembangan Kognitif, (Jakarta: Universitas Terbuka, 2006).

(http://id.wikipedia.org/wiki/Eksplorasi), di akses pada hari Sabtu, 15 Desember 2018, pukul 08.52 WITA. 